\title{
Eroded and Ulcerated Lesion
}

National Cancer Institute

\section{Source}

National Cancer Institute. Eroded and Ulcerated Lesion. NCI Thesaurus. Code C120880.

A finding of both erosion and ulceration in the same lesion. 